\title{
SCIDiC
}

\author{
International Journal of Dentistry and Oral Science (IJDOS) \\ ISSN: 2377-8075
}

\section{Survey On Knowledge And Treatment Of Hot Tooth Syndrome By General Dental Practitioners}

Research Article

R. Preethi Mariona ${ }^{1}$, S. Delphine Priscilla Antony ${ }^{2 *}$

${ }^{1}$ Graduate Student, Saveetha Dental College, Saveetha Institute of Medical and Technical Sciences, Saveetha University, Chennai - 600077, India.

${ }^{2}$ Senior Lecturer, Department of Conservative and Endodontics, Saveetha Dental College, Saveetha Institute of Medical and Technical Sciences, Saveetha University, Chennai- 600077, India.

Abstract

Introduction: Hot tooth is described as the tooth which is diagnosed with irreversible pulpitis with a spontaneous increase in the intensity of pain. This tooth can't be fully anesthetized. The survey is conducted by preparing a questionnaire that could access the knowledge of general dental practitioners about hot teeth and the treatments that they perform.

Aim: A Survey on knowledge and treatment employed for hot tooth syndrome by general dental practitioners.

Objective: A survey that accesses the knowledge and treatment that general dental practitioners perform for hot tooth syndrome.

Materials and Methods: A survey consisting of 10 questions was sent through an online google form. With a total of 54 respondents the survey results were conducted.

Results: All the respondents had knowledge about Hot tooth syndrome. Only $87 \%$ had come across such a situation in treating hot tooth syndrome during their regular clinical practice. $18.5 \%$ of the respondents had the idea of pre- medication to this condition, the others were not aware of the same.

Conclusion: The overall consensus was that a part of the general practitioners were aware of how to treat such patients and few others needed to learn how to handle this situation and the treatment modalities and boost their confidence in treating such patients. This can be achieved by attending workshops or lectures.

Keywords: Hot Tooth; Anesthesia; Pain; Endodontics; Pulpal Anesthesia.

\section{Introduction}

A hot tooth is basically a tooth that is diagnosed with irreversible pulpitis. The intensity of the pain will increase spontaneously from moderate to severe [1]. Inflammatory changes within the pulp progressively worsen as a carious lesion [2] nears the pulp. This further develops and leads to a hot tooth. Hot tooth syndrome can be described as a patient who is sitting in the waiting room, sipping on a large glass of ice water to help control the pain. Such a tooth can't be fully anesthetized. Achieving this has always been a cornerstone in the field of endodontics. Methods like increasing the dosage of anesthesia given or giving supplementary injections to obtain complete pulpal anesthesia. It is very necessary to know that complete anesthesia is obtained before starting the treatment for a hot tooth. The use of an electric pulp tester (EPT) or the application of a cold refrigerant has been shown to accurately determine pulpal anesthesia in teeth with a normal pulp before treatment [3-5]. When debridement is not possible dentists may prescribe strong analgesics and penicillin in an attempt to relieve the pain. In symptomatic teeth with irreversible pulpitis, a high rate of local anesthetic failure is due to prostaglandin-induced sensitization of peripheral nociceptors [6]. Peripheral terminals of nociceptors express receptors that can detect chemical and physical stimuli which results in the activation of ion channels. Inflammatory mediators such as prostaglandins produce their effects by binding to protein receptors. Thus, interventions that decrease the overall concentration of prostaglandins, lead to reduced activation of receptors. Henceforth, prostaglandins are interrupted and it may increase the efficacy of

*Corresponding Author:

S. Delphine Priscilla Antony,

Senior Lecturer, Department of Conservative and Endodontics, Saveetha Dental College, Saveetha Institute of Medical and Technical Sciences, Saveetha University, Chennai600077, India.

Tel: 9790856274

E-mail: delphy.priscilla@gmail.com

Received: May 05, 2021

Accepted: June 20, 2021

Published: June 29, 2021

Citation: R. Preethi Mariona, S. Delphine Priscilla Antony. Survey On Knowledge And Treatment Of Hot Tooth Syndrome By General Dental Practitioners. Int J Dentistry Oral Sci. 2021;8(6):2889-2893. doi: http://dx.doi.org/10.19070/2377-8075-21000563

Copyright: S. Delphine Priscilla Antony ${ }^{\circ} 2021$. This is an open-access article distributed under the terms of the Creative Commons Attribution License, which permits unrestricted use, distribution and reproduction in any medium, provided the original author and source are credited. 
local anesthetics [7]. Previously our team has a rich experience in working on various research projects across multiple disciplines [8-22] Now the growing trend in this area motivated us to pursue this project.

\section{Materials And Method}

\section{Study Sampling}

A cross-sectional study was conducted by preparing a questionnaire with 10 Questions. The questionnaire contained questions that could access the knowledge, attitude, and practice of treating patients with hot tooth syndrome. This survey was conducted among 54 dental practitioners.

\section{Questionnaire}

1. years of practice in dentistry.

2. Are you aware of what is hot tooth syndrome?

a)Yes. B) No

3. If yes, have you treated patients with the hottest?

a) Yes. B) No

4. Does the dosage of anesthesia vary for a normal patient and a patient with a hot tooth?

a) Yes. B) $\mathrm{No}$

5. Does the patient with hot tooth syndrome react the same way as the others? a) Yes. B) no

6. When IANB fails the other methods that can be used are
a) Another IANB
b) Intra ligament injection
c) Intraosseous injections
d) Intra pulpal injection

7. Is any premedication required before delivering local anesthesia to a patient?

a) Yes. B) no

8. Does Tetrodotoxin resistance have a role in the efficacy of local anesthesia?

a) Yes b) No

9. Will premedication with fast-acting anti-inflammatory drugs help in the efficacy of local anesthesia?

a) Yes. B) No

10. What would you prefer for a hot tooth that would be effective?

a) Premedication with NSAIDs's then followed by normal IANB

b) 7 days prior to the treatment, intraosseous injection of methylprednisolone

c) Sublingual triazolam

d) Switch to a different composition of Local anesthesia.

Figure 1: Responses Obtained For Q1.

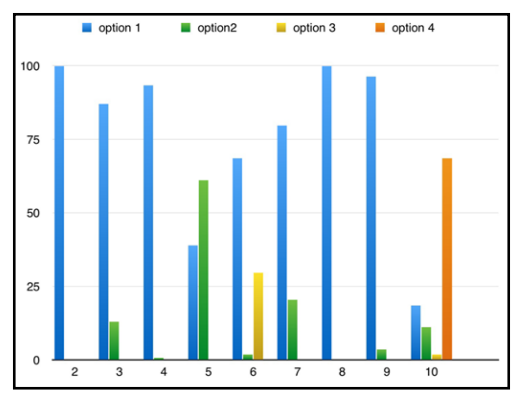

$100 \%$ of the respondents had knowledge about hot tooth.

Figure 2: Responses Obtained For Q2.

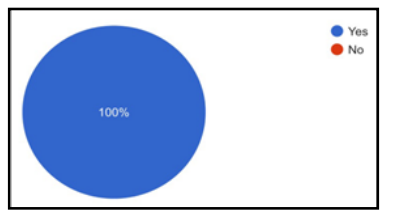

$87 \%$ of the respondents have faced patients with a hot tooth on their dental chair.

Figure 3: Responses Obtained For Q3.

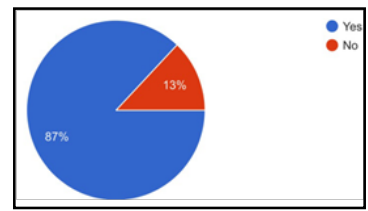

$13 \%$ knew what was a hot tooth but never treated any such. 
Figure 4: Responses Obtained For Q4.

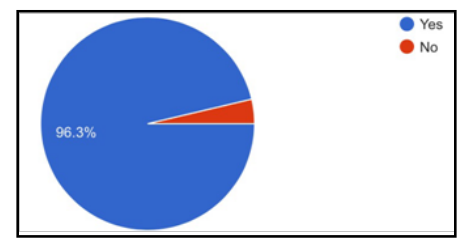

$96.3 \%$ of the respondents strongly feel that the dosage of anaesthesiavaries for a normal patient and a patient with a hot tooth.

Figure 5: Responses Obtained For Q5.

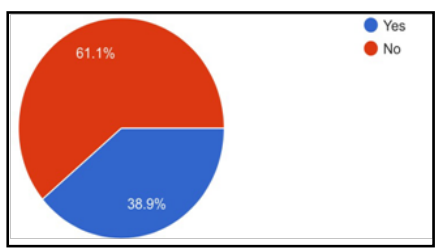

$61.1 \%$ of them say that a patient with a hot tooth doesn't react the same way as another patient.

Figure 6: Responses Obtained For Q6.

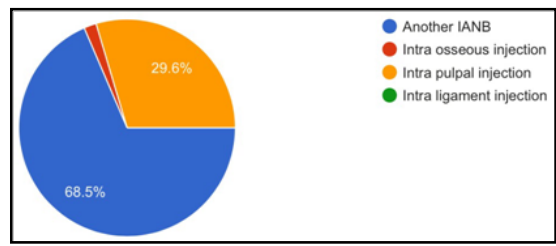

$68.5 \%$ of the respondents said that if IANB fails another IANB will be given. $29.6 \%$ said that they give an intra pulpal injections and the rest preferred intra osseous injections.

Figure 7: Responses Obtained For Q7.

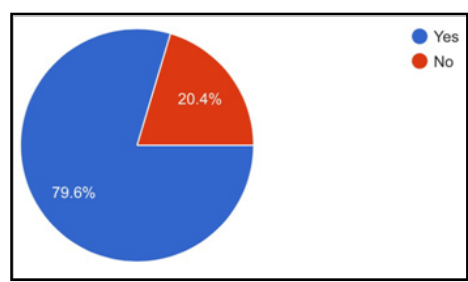

$79.6 \%$ of them insist that premedication is required for patients before delivering Local anaesthesia. $18.5 \%$ of them would follow premedication with NSAID's followed by normal IANB.

Figure 8: Responses Obtained For Q8.

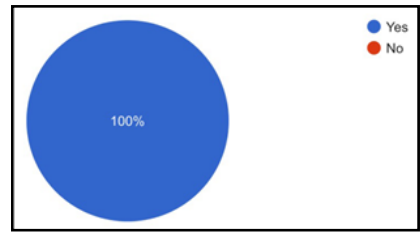

$100 \%$ of them said that tetrodotoxin has a role to play in the efficacy of local anaesthesia

Figure 9: Responses Obtained For Q9.

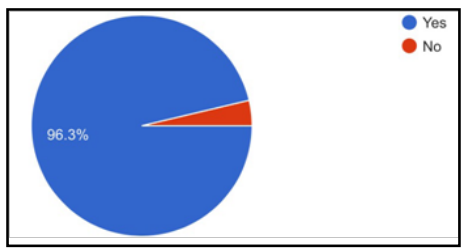

96.3\% said that premedication with fast acting anti inflammatory drugs help in the efficacy of local anesthesia

\section{Results And Discussion}

Hot tooth syndrome is a cornerstone in endodontics. From the survey conducted among general dental practitioners, there are several conclusions that can be obtained.The success of Inferior alveolar nerve block was defined as none or mild pain (VAS recordings) on endodontic access or initial instrumentation [23, 24].
It was found that among the respondents, $100 \%$ of the respondents had knowledge about the hot tooth. $87 \%$ of the respondents have faced patients with a hot tooth on their dental chair. 13\% knew what was a hot tooth but never treated any such. $96.3 \%$ of the respondents strongly feel that the dosage of anesthesia varies for a normal patient and a patient with a hot tooth. The majority of them, I.e, $61.1 \%$ of them say that a patient with a hot tooth doesn't react the same way as another patient. This is because the 
Figure 10: Responses Obtained For Q 10.

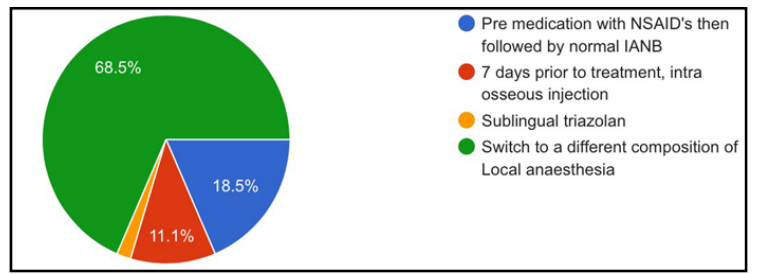

$11.1 \%$ said that 7 days prior to the treatment , intra osseous injection of methylprednisolone would be given and $1.7 \%$ would give Sublingual triazolam.

patient faces intense pain. $38.9 \%$ of them don't feel so. Anti-inflammatory treatments aren't that effective towards the pain. [25]

It was also seen that most patients require an alternative anesthesia method. $[26,27]$ Most endodontic emergencies occur as a result of attempts to relieve symptoms of pulpitis. [28] Among the respondents, $68.5 \%$ of the respondents said that if IANB fails another IANB will be given. $29.6 \%$ said that they give an intra pulpal injections and the rest preferred intraosseous injections. $79.6 \%$ of them insist that premedication is required for patients before delivering Local anesthesia. Articaine solutions had a probability of achieving anesthetic success superior to that of lidocaine. [28, 29] $100 \%$ of the respondents agreed that Tetrodotoxin resistance has a role in the efficacy of local anesthesia [30]. and that pre-emptive oral NSAIDs might have a good effect and are safe in increasing the success rate of IANB [31]. The respondents who insisted on giving premedication felt that premedication with fast-acting anti-inflammatory drugs helps inefficacy of local anesthesia. No response mild electrical stimuli indicates a diagnosis of necrotic tooth $[32,33]$.

It was also evident from the respondents that $68.5 \%$ of them would switch to a different composition of Local anesthesia while $18.5 \%$ of them would follow premedication with NSAID s followed by normal IANB. $11.1 \%$ said that 7 days prior to the treatment, an intra osseous injection of methylprednisolone would be given and $1.7 \%$ would give Sublingual triazolam as premedication which relieves anxiety. A dosage of 600 to $800 \mathrm{mg}$ of ibuprofen showed a significant effect in increasing the success rate of IANB. [30] The dentist administers a combination of the local anesthetic formulation. It must be appreciated that the systemic effects of these combinations follow the principles of summation.[34] Our institution is passionate about high quality evidence based research and has excelled in various fields [35-45].

\section{Conclusion}

Thus the survey revealed the knowledge, attitude, and practice of treatment of hot tooth syndrome among general dental practitioners. This study reveals that practices followed by the practitioners are appropriate and effective. To improve the quality of treatment provided can be improved by attending workshops or lectures. To gain knowledge and keep oneself updated would help in better handling of patients.

\section{Acknowledgement}

The study was supported by the university who provided insights and expertise that greatly assisted the study. We would like to thank the reviewers of the article for their insights and contribu- tions.

\section{References}

[1]. Reader A, Nusstein J, Drum M. Successful local anesthesia for restorative dentistry and endodontics. Quintessence Publishing Company Incorporated; 2011.

[2]. Byers MR, Närhi MV. Dental injury models: experimental tools for understanding neuroinflammatory interactions and polymodal nociceptor functions. Crit Rev Oral Biol Med. 1999;10(1):4-39. Pubmed PMID: 10759425.

[3]. Dreven LJ, Reader A, Beck M, Meyers WJ, Weaver J. An evaluation of an electric pulp tester as a measure of analgesia in human vital teeth. J Endod. 1987 May;13(5):233-8. Pubmed PMID: 3473179.

[4]. Nusstein J, Reader A, Nist R, Beck M, Meyers WJ. Anesthetic efficacy of the supplemental intraosseous injection of $2 \%$ lidocaine with 1:100,000 epinephrine in irreversible pulpitis. J Endod. 1998 Jul;24(7):487-91. Pubmed PMID: 9693577.

[5]. Hsiao-Wu GW, Susarla SM, White RR. Use of the cold test as a measure of pulpal anesthesia during endodontic therapy: a randomized, blinded, placebo-controlled clinical trial. J Endod. 2007 Apr;33(4):406-10. Pubmed PMID: 17368328 .

[6]. Dray A. Inflammatory mediators of pain. British journal of anaesthesia. 1995 Aug 1;75(2):125-31.

[7]. Reisman D, Reader A, Nist R, Beck M, Weaver J. Anesthetic efficacy of the supplemental intraosseous injection of 3\% mepivacaine in irreversible pulpitis. Oral Surg Oral Med Oral Pathol Oral Radiol Endod. 1997 Dec;84(6):676-82. Pubmed PMID: 9431539

[8]. Govindaraju L, Gurunathan D. Effectiveness of Chewable Tooth Brush in Children-A Prospective Clinical Study. J Clin Diagn Res. 2017 Mar;11(3):ZC31-ZC34. Pubmed PMID: 28511505.

[9]. Christabel A, Anantanarayanan P, Subash P, Soh CL, Ramanathan M, Muthusekhar MR, et al. Comparison of pterygomaxillary dysjunction with tuberosity separation in isolated Le Fort I osteotomies: a prospective, multi-centre, triple-blind, randomized controlled trial. Int J Oral Maxillofac Surg. 2016 Feb;45(2):180-5. Pubmed PMID: 26338075.

[10]. Soh CL, Narayanan V. Quality of life assessment in patients with dentofacial deformity undergoing orthognathic surgery--a systematic review. Int J Oral Maxillofac Surg. 2013 Aug;42(8):974-80. Pubmed PMID: 23702370.

[11]. Mehta M, Deeksha, Tewari D, Gupta G, Awasthi R, Singh H, et al. Oligonucleotide therapy: An emerging focus area for drug delivery in chronic inflammatory respiratory diseases. Chem Biol Interact. 2019 Aug 1;308:206215. Pubmed PMID: 31136735.

[12]. Ezhilarasan D, Apoorva VS, Ashok Vardhan N. Syzygium cumini extract induced reactive oxygen species-mediated apoptosis in human oral squamous carcinoma cells. J Oral Pathol Med. 2019 Feb;48(2):115-121. Pubmed PMID: 30451321.

[13]. Campeau PM, Kasperaviciute D, Lu JT, Burrage LC, Kim C, Hori M, et al. The genetic basis of DOORS syndrome: an exome-sequencing study. Lancet Neurol. 2014 Jan;13(1):44-58. Pubmed PMID: 24291220.

[14]. Kumar S, Sneha S. Knowledge and awareness regarding antibiotic prophylaxis for infective endocarditis among undergraduate dental students. Asian Journal of Pharmaceutical and Clinical Research. 2016;154.

[15]. Christabel SL, Gurunathan D. Prevalence of type of frenal attachment and morphology of frenum in children, Chennai, Tamil Nadu. World J Dent. 2015 Oct;6(4):203-7.

[16]. Kumar S, Rahman RE. Knowledge, awareness, and practices regarding biomedical waste management among undergraduate dental students. Asian Journal of Pharmaceutical and Clinical Research. 2017;10(8):341.

[17]. Sridharan G, Ramani P, Patankar S. Serum metabolomics in oral leukoplakia and oral squamous cell carcinoma. J Cancer Res Ther. 2017 JulSep;13(3):556-561. Pubmed PMID: 28862226.

[18]. Ramesh A, Varghese SS, Doraiswamy JN, Malaiappan S. Herbs as an anti- 
oxidant arsenal for periodontal diseases. J Intercult Ethnopharmacol. 2016 Jan 27;5(1):92-6. Pubmed PMID: 27069730.

[19]. Thamaraiselvan M, Elavarasu S, Thangakumaran S, Gadagi JS, Arthie T. Comparative clinical evaluation of coronally advanced flap with or without platelet rich fibrin membrane in the treatment of isolated gingival recession. J Indian Soc Periodontol. 2015 Jan-Feb;19(1):66-71. Pubmed PMID: 25810596.

[20]. Thangaraj SV, Shyamsundar V, Krishnamurthy A, Ramani P, Ganesan K, Muthuswami M, et al. Molecular Portrait of Oral Tongue Squamous Cell Carcinoma Shown by Integrative Meta-Analysis of Expression Profiles with Validations. PLoS One. 2016 Jun 9;11(6):e0156582. Pubmed PMID: 27280700.

[21]. Ponnulakshmi R, Shyamaladevi B, Vijayalakshmi P, Selvaraj J. In silico and in vivo analysis to identify the antidiabetic activity of beta sitosterol in adipose tissue of high fat diet and sucrose induced type- 2 diabetic experimental rats. Toxicol Mech Methods. 2019 May;29(4):276-290. Pubmed PMID: 30461321.

[22]. Ramakrishnan M, Bhurki M. Fluoride, Fluoridated Toothpaste Efficacy And Its Safety In Children-Review. International Journal of Pharmaceutical Research. 2018 Oct 1;10(04):109-14.

[23]. Kennedy S, Reader A, Nusstein J, Beck M, Weaver J. The significance of needle deflection in success of the inferior alveolar nerve block in patients with irreversible pulpitis. J Endod. 2003 Oct;29(10):630-3. Pubmed PMID: 14606783.

[24]. Rotstein I, Ingle JI, editors. Ingle's endodontics. PMPH USA; 2019 Jun 1.

[25]. Ianiro SR, Jeansonne BG, McNeal SF, Eleazer PD. The effect of preoperative acetaminophen or a combination of acetaminophen and Ibuprofen on the success of inferior alveolar nerve block for teeth with irreversible pulpitis. J Endod. 2007 Jan;33(1):11-4. Pubmed PMID: 17185119.

[26]. Boopathi T, Sebeena M, Sivakumar K, Harikaran J, Karthick K, Raj A. Supplemental pulpal anesthesia for mandibular teeth. J Pharm Bioallied Sci. 2013 Jun;5(Suppl 1):S103-8. Pubmed PMID: 23946560.

[27]. Claffey E, Reader A, Nusstein J, Beck M, Weaver J. Anesthetic efficacy of articaine for inferior alveolar nerve blocks in patients with irreversible pulpitis. J Endod. 2004 Aug;30(8):568-71. Pubmed PMID: 15273637.

[28]. Oguntebi BR, DeSchepper EJ, Taylor TS, White CL, Pink FE. Postoperative pain incidence related to the type of emergency treatment of symptomatic pulpitis. Oral Surg Oral Med Oral Pathol. 1992 Apr;73(4):479-83. Pubmed PMID: 1574311.

[29]. Katyal V. The efficacy and safety of articaine versus lignocaine in dental treatments: a meta-analysis. J Dent. 2010 Apr;38(4):307-17. Pubmed PMID: 20006669

[30]. Gold MS, Reichling DB, Shuster MJ, Levine JD. Hyperalgesic agents increase a tetrodotoxin-resistant $\mathrm{Na}+$ current in nociceptors. Proc Natl Acad Sci U S A. 1996 Feb 6;93(3):1108-12. Pubmed PMID: 8577723.

[31]. Li C, Yang X, Ma X, Li L, Shi Z. Preoperative oral nonsteroidal anti-inflammatory drugs for the success of the inferior alveolar nerve block in irreversible pulpitis treatment: a systematic review and meta-analysis based on randomized controlled trials. Quintessence Int. 2012 Mar;43(3):209-19. Pubmed PMID: 22299121.

[32]. Nivethithan T, Raj JD. Endodontic pain-cause and management: A review.
International Journal of Pharmaceutical Sciences and Research. 2015 Jul $1 ; 6(7): 2723$.

[33]. Swetha TV, Haripriya S. Survey on diagnosis and management of reversible pulpitis among general practitioners in Chennai. Drug Invention Today. 2019 Sep 1;11(9).

[34]. Raman S, Madhulaxmi M, Jeevanandan G. Local anesthetics-A review on toxicity. Drug Invention Today. 2019 Mar 15;12(3).

[35]. Vijayashree Priyadharsini J. In silico validation of the non-antibiotic drugs acetaminophen and ibuprofen as antibacterial agents against red complex pathogens. J Periodontol. 2019 Dec;90(12):1441-1448. Pubmed PMID: 31257588.

[36]. J PC, Marimuthu T, C K, Devadoss P, Kumar SM. Prevalence and measurement of anterior loop of the mandibular canal using CBCT: A cross sectional study. Clin Implant Dent Relat Res. 2018 Aug;20(4):531-534. Pubmed PMID: 29624863.

[37]. Ramesh A, Varghese S, Jayakumar ND, Malaiappan S. Comparative estimation of sulfiredoxin levels between chronic periodontitis and healthy patients - A case-control study. J Periodontol. 2018 Oct;89(10):1241-1248. Pubmed PMID: 30044495 .

[38]. Ramadurai N, Gurunathan D, Samuel AV, Subramanian E, Rodrigues SJL. Effectiveness of 2\% Articaine as an anesthetic agent in children: randomized controlled trial. Clin Oral Investig. 2019 Sep;23(9):3543-3550. Pubmed PMID: 30552590.

[39]. Sridharan G, Ramani P, Patankar S, Vijayaraghavan R. Evaluation of salivary metabolomics in oral leukoplakia and oral squamous cell carcinoma. J Oral Pathol Med. 2019 Apr;48(4):299-306. Pubmed PMID: 30714209.

[40]. Ezhilarasan D, Apoorva VS, Ashok Vardhan N. Syzygium cumini extract induced reactive oxygen species-mediated apoptosis in human oral squamous carcinoma cells. J Oral Pathol Med. 2019 Feb;48(2):115-121. Pubmed PMID: 30451321.

[41]. Mathew MG, Samuel SR, Soni AJ, Roopa KB. Evaluation of adhesion of Streptococcus mutans, plaque accumulation on zirconia and stainless steel crowns, and surrounding gingival inflammation in primary molars: randomized controlled trial. Clin Oral Investig. 2020 Sep;24(9):3275-3280. Pubmed PMID: 31955271.

[42]. Samuel SR. Can 5-year-olds sensibly self-report the impact of developmental enamel defects on their quality of life? Int J Paediatr Dent. 2021 Mar;31(2):285-286. Pubmed PMID: 32416620.

[43]. R H, Ramani P, Ramanathan A, R JM, S G, Ramasubramanian A, et al. CYP2 C9 polymorphism among patients with oral squamous cell carcinoma and its role in altering the metabolism of benzo[a]pyrene. Oral Surg Oral Med Oral Pathol Oral Radiol. 2020 Sep;130(3):306-312. Pubmed PMID: 32773350.

[44]. Chandrasekar R, Chandrasekhar S, Sundari KKS, Ravi P. Development and validation of a formula for objective assessment of cervical vertebral bone age. Prog Orthod. 2020 Oct 12;21(1):38. Pubmed PMID: 33043408.

[45]. Vijayashree Priyadharsini J, Smiline Girija AS, Paramasivam A. In silico analysis of virulence genes in an emerging dental pathogen A. baumannii and related species. Arch Oral Biol. 2018 Oct;94:93-98. Pubmed PMID: 30015217. 